\title{
Peranan Kelompok Teman Sebaya di Sekolah dalam Meningkatkan Komunikasi Interpersonal Siswa
}

\author{
Feida Noorlaila Isti'adah, Rahmat Permana
}

KORESPONDEN PENULIS:

Feida Noorlaila Isti'adah

Universitas Muhammadiyah

Tasikmalaya

Jalan Tamansari, Gobras, Tasikmalaya,

Jawa Barat, Indonesia

Email:feida@umtas.ac.id

Rahmat Permana

Universitas Muhammadiyah

Tasikmalaya

Jalan Tamansari, Gobras, Tasikmalaya, Jawa Barat, Indonesia

Email: rahmat.pgsd@umtas.ac.id

Halaman

8-13

\begin{abstract}
This study aimed to find out to what extent the role of peer group at school towards the students' interpersonal communication This was a descriptive quantitative study. The number of subject of this study were 172 students of class the tenth-grade students of all vocational high school in Singaparna sub-district with taken by using simple random sampling. The data of this study were analyzed statistically by using linear regression test, the coefficient of correlation test, and coefficient of determination test. Based on the data analysis, This study found that there was a significant relationship between peer group at school and students' interpersonal communication. The result of this study was beneficial for school counselor in directing the students about the importance of positive interaction within the peer group and the importance of developing the students' interpersonal communication.
\end{abstract}

Keywords: peer group, interpersonal communication, student

\section{ABSTRAK}

Studi bertujuan untuk mengetahui seberapa besar peranan kelompok teman sebaya di sekolahterhadapkomunikasi interpersonalsiswa. Studimenggunakanpendekatankuantitatifdeskriptif. Subyek dalam studi ini yaitu siswa kelas X SMK Se-Kecamatan Singaparna sebanyak 172 siswa yang diambil dengan simple random sampling. Adapun analisis data yang diperoleh dari lapangan menggunakan perhitungan statistik berupa uji linearitas regresi, uji koefisien korelasi, dan uji koefisien determinasi. Berdasarkan analisis data diperoleh hasil penelitian terdapat hubungan yang signifikan antara kelompok teman sebaya di sekolah dengan komunikasi interpersonal siswa. Hasil studimemberikan alternatif strategi bagi guru bimbingan dan konseling untuk membantu mengembangkan komunikasi interpersonal siswa melalui konseling teman sebaya.

Kata kunci:kelompok teman sebaya, komunikasi interpersonal, siswa 


\section{PENDAHULUAN}

Masa remaja adalah masa dimana lingkungan memiliki pengaruh paling besar dalam kehidupan mereka. Remaja mengalami kebingungan sehingga berusaha mencari tempat yang aman bagi dirinya. Remaja mulai berpikir kritis, memperluas pergaulan dan berpaling pada temanteman sebaya yang mengerti gejolak emosi yang dirasakannya. Pada awal masa remaja, penyesuaian diri dengan lingkungan, terutama lingkungan sekolah dan teman sebaya memiliki pengaruh kuat dalam kehidupan remaja. Sehubungan dengan hal tersebut, Santrock (Desmita, 2007) mengemukakan bahwa remaja banyak menghabiskan waktunya dengan teman-teman sebaya lebih dari 40\%. Pendapat tersebut diperkuat oleh Hurlock (1999) yang menerangkan bahwa karena remaja cenderung lebih banyak berada di luar rumah bersama kelompok teman sebaya, maka pengaruh teman sebaya pada sikap, pembicaraan, minat, penampilan, dan perilaku lebih besar daripada pengaruh keluarga.

Penelitian yang dilakukan oleh Wardani, S.Y.,\& Trinani, R.P.,(2015)di SMP Negeri 8 Madiun menunjukan bahwa konseling sebaya efektif untuk meningkatkan perilaku prososial siswa. Di dalam perilaku prososial terdapat komunikasi interpersonal sebagai salah satu komponennya. Kelompok teman sebaya merupakan faktor paling dominan yang berperan mempengaruhi atau mengubah perilaku siswa sehingga akan berdampak pada kehidupan sosial siswa.

Memiliki kemampuan komunikasi interpersonal yang baik akan memudahkan seorang siswa dalam mengutarakan gagasan, ide, atau pendapat dalam kehidupannya seharihari. Namun pada kenyataannya, berangkat dari fenomena yang telah dijelaskan pada latar belakang, masih ada siswa yang kurang memiliki kemampuan dalam komunikasi interpersonal dengan orang lain. Contohnya sering terjadi pertengkaran dalam kelompok teman sebaya dikarenakan adanya kesalahpahaman antara siswa, dan juga terjadi kesalahan dalam menyampaikan informasi kepada temannya dikarenakan siswa kurang bisa mengkomunikasikan pembicaraannya secara tepat dan jelas kepada orang lain. Dalam kegiatan belajar mengajar di sekolah terutama yang berhubungan dengan komunikasi, keluhan yang paling banyakdari guru matapelajaran dan wali kelas adalahsiswa kurang bisa mengkomunikasikan dan mengekspresikan ide, pendapat, pemikirannya kepada orang lain secara tepat, jelas, dan efektif.

Upaya peningkatan komunikasi interpersonal siswa sangat ditentukan dan dipengaruhi oleh seberapa besar kontribusi keterlibatan siswadalam peer group di sekolah terhadap komunikasi interpersonal siswa. Apabila sikap dan perilaku yang dimunculkan oleh kelompok teman sebaya sesuai dengan aturan sekolah, norma masyarakat, moral atau agama sehingga dapat dipertanggungjawabkan, maka remaja tersebut akan menampilkan interaksi sosial dan komunikasi interpersonal yang baik. Menurut Ali (2004) Kelompok teman sebaya memegang peranan penting dalam kehidupan remaja. Remaja sangat ingin diterima dan dipandang sebagai anggota kelompok teman sebaya, baik di sekolah maupun di luar sekolah. Oleh karenanya, mereka cenderung bertingkah laku seperti tingkah laku kelompok sebayanya.

Tujuan yang ingin dicapai dalamstudi ini yaitu untuk mengetahui gambaran empirik mengenai keterlibatan siswa dalam peer group di sekolah dan komunikasi interpersonal siswa SMK se-Kecamatan Singaparna serta untuk mengetahui gambaran empirik mengenai seberapa besar kontribusi keterlibatan siswa di dalam peer group di sekolah terhadap komunikasi interpersonal siswa. Hasil studi memberikan alternatif strategi bagi guru bimbingan dan konseling untuk membantu mengembangkan komunikasi interpersonal siswa melalui konseling teman sebaya.

\section{METODE PENELITIAN}

Pendekatan penelitian yang digunakan dalam studi ini yaitu menggunakan pendekatan penelitian kuantitatif. Jenis penelitian yang dipergunakan dalam studi ini adalah jenis deskriptif analitik yaitu metode untuk mendapatkan gambaran secara sistematis, faktual, dan akurat mengenai fakta-fakta dan sifat populasi tertentu, kemudian dianalisis dan interpretasi dalam bentuk kesimpulan serta rekomendasi. Subyek dalam studi ini adalah siswa kelas X SMK se-Kecamatan Singaparna sebanyak 172 orang. Teknik pengambilan sampel menggunakan simple random sampling. Alat yang digunakan untuk pengumpulan data pada studi ini adalah angket tertutup dalam bentuk skala Likert. Teknik analisis data yang digunakan adalah teknik analisis persentase, setelah semua jawaban terkumpul selanjutnya ditabulasikan. peneliti juga melakukan analisis 
data dengan uji linearitas regresi, uji koefisien korelasi serta uji koefisien determinasi.

\section{HASIL DAN PEMBAHASAN}

Hasil uji signifikansi korelasi sebagaimana tabel 1 menunjukkan> 0.05, maka hubungan antara kedua variabel tersebut tidak signifikan, dan sebaliknya jika nilai signifikansi $<0.05$ maka hubungan antara kedua variabel tersebut signifikan. Dari tabel dapat dilihat nilai signifikansi sebesar 0.000 sehingga dapat dikatakan bahwa kedua variabel secara nyata berkorelasi secara signifikan. Dengan kata lain terdapat hubungan yang signifikan antara kelompok teman sebaya di sekolah dengan komunikasi interpersonal siswa. Selain itu dapat dilihat koefisien korelasi sebesar 0.395 artinya bahwa antara kelompok teman sebaya di sekolah dengan komunikasi interpersonal siswa mempunyai hubungan yang rendah. Oleh karena itu jika semakin besar keterlibatan siswa dalam peer group di sekolah maka komunikasi interpersonal siswa pun semakin besar sebagaimana Tabel 1 .

Tabel 1

Hasil Uji Koefisien Korelasi

\begin{tabular}{llll}
\hline & & $\begin{array}{l}\text { Kel. Teman } \\
\text { Sebaya }\end{array}$ & $\begin{array}{l}\text { Kom. } \\
\text { Interpersonal }\end{array}$ \\
\hline $\begin{array}{lll}\text { Kelompok Teman } \\
\text { Sebaya }(\mathrm{x})\end{array}$ & $\begin{array}{l}\text { Pearson } \\
\text { Correlation }\end{array}$ & 1 & $.395^{* *}$ \\
& Sig. (2-tailed) &. & .000 \\
& $\mathrm{~N}$ & 172 & 172 \\
& Pearson & $.395^{* *}$ & 1 \\
& Correlation & & \\
Kom. Interpersonal & Sig. (2-tailed) & .000 &. \\
(Y) & $\mathrm{N}$ & 172 & 172 \\
\hline
\end{tabular}

Tabel 2

Hasil Uji Koefisien Determinasi

\begin{tabular}{lllll}
\hline Model & $R$ & R Square & $\begin{array}{l}\text { Adjusted R } \\
\text { Square }\end{array}$ & Std. Error \\
\hline 1 & $.395^{a}$ & .156 & .151 & 10.737 \\
\hline
\end{tabular}

Untuk melihat besarnya kontribusi kelompok teman sebaya di sekolah terhadap komunikasi interpersonal siswa dapat dilihat dari koefisien determinasi atau $r^{2}$ pada Tabel 2.

Dari Tabel 2 nilai koefisien determinasi ( $\mathrm{R}$ Square) atau $r^{2}$ yaitu sebesar 0.156. Hal ini berarti bahwa 15.6\% varians dari komunikasi interpersonal siswa dipengaruhi oleh kelompok teman sebaya di sekolah. Dan sisanya sebesar $84.4 \%$ dijelaskan oleh sebab-sebab lain yang tidak diteliti dalam penelitian.

Menurut Ali (2004) Kelompok teman sebaya memegang peranan penting dalam kehidupan remaja. Remaja sangat ingin diterima dan dipandang sebagai anggota kelompok teman sebaya, baik di sekolah maupun di luar sekolah. Oleh karenanya, mereka cenderung bertingkah laku seperti tingkah laku kelompok sebayanya. Agar anak dapat menyesuaikan diri dengan tuntutan sosialnya, menurut Hurlock (Noorlaila, 2011) diperlukan tiga proses sosialisali yaitu Belajar berperilaku yang dapat diterima secara sosial artinya bahwa dalam kelompok terdapat standar bagi para anggotanya. Individu harus mengetahui perilaku yang diterima oleh anggota kelompoknya. Belajar memainkan peran yang dapat diterima artinya bahwa setting kelompok memiliki kebiasaan yang telah ditentukan dan disepakati oleh anggotanya. Perkembangan sikap sosial, artinya bahwa anak di tuntut untuk bergaul dengan baik serta menyukai orang lain dan aktivitas sosialnya seperti sikap positif atau negatif, perasaan suka atau tidak suka terhadap aktivitas sosial.

Sosialisasi yang dilakukan siswa di sekolah disertai dengan adanya hubungan interpersonal. Dalam hubungan interpersonal tersebut siswa akan mengembangkan pola respon tertentu dalam berperilaku yaitu dengan cara berkomunikasi (Diponegoro, 2012). Oleh karena itu mengingat begitu pentingnya keterampilan komunikasi interpersonal bagi siswa dalam upaya meningkatkan hubungan sosial dengan orang lain serta prestasi akademik dan non akademik siswa.Wagner (Noorlaila, 2011) menjelaskan bahwa kelompok sebaya tampaknya dapat membantu perkembangan kepribadian remaja, ksususnya dalam empat area yaitu: 1) Remaja belajar bagaimana berinteraksi dengan orang lain melalui kelompok sebaya. Kemampuan untuk dapat bersama dengan orang lain dan diterima oleh orang lain merupakan suatu cara untuk dapat melakukan penyesuaian diri secara kuat. Kegagalan untuk mengembangkan keterampilan sosial merupakan sesuatu yang mendahului perubahan remaja dan masalah dalm kesehatan mental pada masa dewasa. 2) Kelompok sebaya memberikan suatu gambaran dimana remaja dapat membentuk dan 
memperjelas standar moral dan sistem moral mereka. Bagian dari proses pembentukan identitas ego dewasa adalah eksplorasi dan evaluasi dari pilihan sistem nilai melebihi orang tua mereka. Kelompok sebaya akan memberikan suatu perlindungan dan dukungan kelompok dalam mencoba sistem itu. 3) Sewaktu mengalami tekanan emosional, khususnya tekanan dalam hubungan dengan keluarga, kelompok sebaya dapat memberikan dukungan emosional.

Kelompok sebaya dapat berfungsi sebagai pemberi petunjuk dan penasihat. Klompok sebaya dapat membantu sebagai pemberi jawaban atas pertanyaan dan sikap terhadap seks, alkohol, dan tingkah laku lainnya. Hasil penelitian menunjukan nilai signifikansi sebesar 0.000 dengan kata lain terdapat hubungan yang signifikan antara kelompok teman sebaya di sekolah dengan komunikasi interpersonal siswa.

Menurut Hartley (1999) komunikasi dapat dikatakan sebagai suatu tarian, karena dalam setiap prosesnya ada pihak atau partner lain yang harus dapat sejalan dalam mewujudkan tujuannya. Lebih lanjut Hartley mengungkapkan komunikasi interpersonal terjadi antara dua orang atau lebih yang berada di tempat yang sama dan menyadari kehadiran satu sama lain, bersifat langsung tidak peduli seberapa halus atau disengaja. Lilliweri (1997) mengungkapkan bahwa komunikasi interpersonal adalah pengisian pesan dari seseorang dan diterima oleh orang lain dalam hal ingin mengubah sikap, pendapat atau perilaku seseorang karena sifatnya yang dialogis, yaitu berupa percakapan. Menurut Devito (Maharani, 2009) dalam aktivitas komunikasi interpersonal sering kali terjadi ketakutan untuk berkomunikasi. Ketakutan berkomunikasi mencakup rasa malu, tidak mau berkomunikasi, demam panggung, atau segan berkomunikasi.

Lebih lanjut Devito mengemukakan bahwa ketakutan berkomunikasi mengacu pada kondisi takut atau cemas mengenai interaksi komunikasi. Individu mengembangkan perasaan negatif dan memprediksi hasil negatif sebagai hasil dari interaksi komunikasi. Individu yang takut berkomunikasi merasa apapun keberhasilan yang diraihnya dengan berkomunikasi akan terkalahkan oleh rasa takut. Bagi mereka yang memiliki ketakutan tinggi untuk berkomunikasi, interaksi dalam bentuk komunikasi tidak seban- ding dengan rasa takut yang dirasakan.

Ketakutan berkomunikasi ada yang merupakan sifat (trait); individu takut berkomunikasi pada situasi apapun. Ketakutan komunikasi yang terkait situasi (state) terkait pada situasi spesifik, seperti seseorang yang takut untuk berbicara di muka umum namun tidak mengalami masalah dalam komunikasi diadik (dua orang). Ketakutan berkomunikasi bersifat kontinum. Artinya setiap orang mengalami ketakutan, namun ada yang kadarnya lemah dan ada yang besar.

Terdapat beberapa faktor yang memberikan kontribusi terhadap ketakutan berkomunikasi, yaitu: 1) Kurangnya keterampilan dan pengalaman berkomunikasi; 2) Kadar evaluasi yang dirasakan oleh subyek; 3) Status yang lebih rendah; 4) Mencolok atau tidaknya situasi saat individu berkomunikasi; 5) derajat prediksi dari suatu situasi. Semakin situasi tidak bisa diprediksi, semakin tinggi tingkat ketakutan yang akan dirasakan; 6) derajat ketidaksamaan. Semakin individu merasa adanya ketidaksamaan antara dirinya dengan pendengar, semakin individu merasa cemas; 7) pengalaman sebelumnya akan keberhasilan dan kegagalan (Maharani, 2009).

Komunikasi interpersonal menurut Brooks (Hargie, 2005) merupakan proses mencari informasi, pemaknaan, dan perasaan yang ditunjukan oleh seseorang baik pesan secara verbal maupun non verbal. Tingkatan dan konteks komunikasi interpersonal mewakili satuan terkecil interaksi manusia sebelum beranjak ke dalam tingkatan dan berbagai jangkauan yaitu komunikasi kelompok, komunikasi organisasi, komunikasi publik, dan komunikasi massa. Komunikasi interpersonal sangatlah penting dalam kehidupan siswa terutama dalam bergaul dengan teman sebayanya(Gumilang, 2015). Karena sebagai individu yang sedang mencari jati diri, sering kali siswa kesulitan dalam berkomunikasi dengan orang lain. Siswa yang kurang memiliki kemampuan berkomunikasi interpersonal akan merasa rendah diri saat akan mengungkapkan pendapatnya. Siswa yang kurang mampu untuk berkomunikasi interpersonal dengan orang lain dapat membuat siswa tersebut merasa malu untuk memulai suatu hubungan pertemanan.

Melalui interaksi sosial dengan kelompok teman sebaya, seorang remaja disekolah dalam hal ini siswa akan 
cenderung mengikuti cara berpakaian, berbicara dan berperilaku seperti anggota kelompok teman sebayanya (Waters, Cross, \& Shaw.,2010). Penyesuaian dengan gaya hidup anggota kelompok teman sebaya tersebut akan menambah kesolidan dan memperkuat ikatan emosional diantara mereka (Kerpelman \& White, 2006). Begitu juga jika anggota kelompok teman sebaya terlibat dalam kegiatan yang negatif, seperti membolos, melanggar peraturan sekolah, mencuri, tawuran, maka siswa akan cenderung mengikutinya tanpa mempedulikan akibat yang akan menimpa dirinya. Lingkungan sosial akademik juga berpengaruh terhadap kemampuan komunikasi interpersonal siswa (Kiuru, 2014). Terkait dengan proses pembelajaran, interaksi sosial dalam kelompok teman sebaya berperan dalam merubah, mempengaruhi, atau memperbaiki perilaku siswa dalam mengikuti proses pembelajaran (Utami, 2014).

Menurut Watzlawick (Koprowska, 2008) seseorang tidak dapat tidak berkomunikasi. Seseorang akan terisolasi jika kurang berkomunikasi dengan orang lain. Hal ini dikhawatirkan dapat menimbulkan permasalahan yang kompleks. Penelitian yang dilakukan oleh Segrin dan Flora (Hargie, 2005) menunjukan bahwa seseorang yang mempunyai komunikasi yang baik dalam kehidupannya mempunyai level yang paling tinggi dalam mengatasi stres, dapat beradaptasi dengan lingkungannya, dan lebih kecil kemungkinan untuk menderita depresi, kesepian atau kecemasan. Bentuk komunikasi yang efektif dilakukan yaitu komunikasi interpersonal.

Montgomery (2006) mengungkapkan komunikasi interpersonal terjadi ketika dua orang atau lebih berinteraksi dengan cara melibatkan perilaku verbal dan nonverbal, pertukaran interpersonal, dan penggunaan perilaku yang sesuai dengan tujuan spesifik dari interaksi komunikatif, hasil yang diinginkan adalah perubahan dalam sikap, perilaku, atau keyakinan dari interactant (orang dengan siapa kita berkomunikasi), dan mungkin resolusi yang konstruktif.Brooks (Hargie, 2005) mendefinisikankomunikasi interpersonal sebagai proses mencariinformasi, pemaknaan dan perasaan yang ditunjukan oleh seseorang baik pesan secara verbal maupun non verbal. Fokus komunikasi interpersonal menekankan proses orang berinteraksi dari pada isi verbal dari interaksi, menekankan perilaku dan keterampilan memperpanjang alternatif yang tersedia untuk komunikasi interpersonal. Hal ini mencakup dimensi afektif serta kognitif yang diambil dari perilaku dan ilmu lainnya serta dari humaniora (Ramaraju, 2012).

Guna mengetahui kontribusi variabel independent terhadap variabel dependent dari abel hasil uji koefisien determinasi dapat diketahui bahwa variabel kelompok teman sebaya memberikan kontribusi sebesar $15.6 \%$. Artinya bahwa komunikasi interpersonal siswa dapat di tentukan oleh tinggi rendahnya keterlibatan siswa dalam kelompok teman sebaya di sekolah.

Dengan kata lain baik tidaknya keterlibatan siswa dalam kelompok teman sebaya di sekolah secara langsung ataupun tidak, akan berpengaruh terhadap komunikasi interpersonal siswa. Apabila keterlibatan siswa dalam kelompok teman sebaya di sekolah meningkat kearah yang positif, maka hal tersebut akan mengakibatkan komunikasi interpersonal siswa juga meningkat. Sebaliknya apabila keterlibatan siswa dalam kelompok teman sebaya di sekolah dinilai mengalami perubahan kearah negatif, maka komunikasi interpersonal siswa juga akan mengalami penurunan. Hal ini sesuai dengan pendapat Syamsu Yusuf (2016) yang mengungkapkan bahwa pada masa remaja pengaruh kelompok sangatlah kuat mereka cenderung untuk berkumpul dan berinteraksi dalam kelompok sebayanya, dengan adanya dinamika dan pengaruh dalam kelompok, remaja dapat merumuskan, memperbaiki dan meningkatkan komunikasi interpersonal melalui kelompok yang dimilikinya. Sehingga dengan adanya interaksi dan dinamika yang berkembang dalam kelompok (peer group) itulah yang pada akhirnya akan mengembangkan komunikasi interpersonal pada remaja.

\section{SIMPULAN}

Dari hasil penelitian yang telah dilakukan dapat disimpulkan, terdapat hubungan yang positif dan signifikan antara kelompok teman ssebaya di sekolah dengan komunikasi interpersonal siswa. Artinya bahwa apabila keterlibatan siswa dalam kelompok teman sebayadi sekolah meningkat kearah yang positif, maka hal tersebut akan mengakibatkan komunikasi interpersonal siswa juga meningkat kearah positif. Sebaliknya apabila keterlibatan 
siswa dalam kelompok teman sebaya di sekolah dinilai mengalami perubahan kearah negatif, maka komunikasi interpersonal siswa juga akan mengalami kemunduran kearah negatif. Dan besaran kontribusi kelompok teman sebaya di sekolah terhadap komunikasi interpersonal siswa sebesar $15.6 \%$.

Oleh karena itu guru dan khususnya guru bimbingan dan konseling hendaknya memberikan penjelasan dan pengarahan kepada siswa tentang pentingnya berinteraksi secara positif dalam kelompok teman sebaya agar siswa mampu memilih karakteristik kelompok yang memberikan pengaruh positif terhadap perkembangan komunikasi interpersonal siswa.

\section{REFERENSI}

Desmita. (2007). PsikologiPerkembangan. Bandung: PT. RemajaRosdakarya.

Diponegoro, Ahmad Muhammad. (2012). Hubungan Pola Asuh Otoritatif, Kontrol Diri, Ketrampilan Komunikasi dengan Agresivitas Siswa. PSIKOPEDAGOGIA Jurnal Bimbingan dan Konseling, 2(2), 101 115.

Gumilang, Galang Surya. (2015). Evaluasi Keterampilan Komunikasi Interpersonal antara Konselor dengan Siswa, Staf Sekolah, dan Orangtua di SMKN Kota Malang. PSIKOPEDAGOGIA Jurnal Bimbingan dan Konseling, 4 (1), 83-87.

Hargie, Owen \& Dickson, David. (2005). Skilled interpersonal Communication (fourth Edition). USA: Routledge.

Hartley, Peter. (1999). Interpersonal Communication $\left(2^{\text {nd }} e d\right)$. New York: Routledge

Hurlock, E. B (1999). Alih Bahasa Istiwidayati \& Soedjarwo. Psikologi Perkembangan: Suatu Pendekatan Sepanjang Rentang Kehidupan. Jakarta: Erlangga.

Kiuru. (2014). Task-Focused Behavior Mediates the Associations Between Supportive Interpersonal Environments and Students' Academic Performance. Psychological Science, 25 (2), 1018.

Kerpelman \& White. (2006). Interpersonal Identity and Social Capital: The Importance of Commitment for Low Income, Rural, African American Adolescents. Journal of Black Psychology, 32(2), 219.

Koprowska, Juliet. (2008). Communication and Interpersonal Skill in Social Work. Southerhay East: Learn- ing Matters Ltd.

Lilliweri, A. (1997). Komunikasi antar pribadi. Bandung:Cipta Aditya Bakti.

Maharani, Anita et al. (2009). Faktor-faktor pendukung kompetensi interpersonal: studi kasus pada mahasiswa tingkat pertama di Universitas Paramadina. Jurnal Ilmu Komunikasi. 6(1), 25-44.

Montgomery, Judy. (2006). The Art of InterpersonalCommunication. Journal of Communication Disorder Quarterly, 28(1), 56-58.

Noorlaila. (2011). Kontribusi Keterlibatan Siswa dalam Peer Group di Sekolah terhadap Kedisiplinan Siswa. Skripsi Sarjana pada PPB FIP UPI. Tidak Diterbitkan.

Utami, Rah. (2014). Pengaruh Komunikasi Kelompok Teman Sebaya (Peer Group) terhadap Perilaku Belajar Mahasiswa di Bandung. Jurnal. Universitas Telkom.5(4).

Sarwono, S.W. (1999). Psikologi Sosial: Psikologi Kelompok dan Psikologi Terapan. Jakarta: Balai Pustaka.

Wardani, S.Y.,\& Trinani, R.P.,(2015). Konseling Sebaya Sebagai Metode untuk Meningkatkan Perilaku Prososial Siswa. PSIKOPEDAGOGIA Jurnal Bimbingan dan Konseling, 4(2), 97-92

Waters, Cross, \& Shaw. (2010). How Important are School and Interpersonal Student Characteristics in Determining Later Adolescent School Connectedness, by School Sector?. Australian Journal of Education, 54 (2), 223.

Yusuf, Syamsu. L. N (2001). Psikologi Perkembangan Anak dan Remaja. Badung: Remaja Rosdakarya. 